\title{
DDX5 wt Allele
}

National Cancer Institute

\section{Source}

National Cancer Institute. DDX5 wt Allele. NCI Thesaurus. Code C97461.

Human DDX5 wild-type allele is located in the vicinity of $17 q 21$ and is approximately $8 \mathrm{~kb}$ in length. This allele, which encodes probable ATP-dependent RNA helicase DDX5, plays a role in the regulation of both RNA splicing and ATP hydrolysis. A chromosomal translocation of this gene and the ETV4 gene may be associated with prostate cancer. 